\title{
Iron index as an organic matter decay intensity indicator in a shallow groundwater system highly contaminated with phenol (case study in northern Poland)
}

\author{
Dorota Pierri $^{1}$ (D) Mariusz Czop ${ }^{1}$ (D)
}

Received: 9 September 2019 / Accepted: 1 June 2020 / Published online: 7 June 2020

(c) The Author(s) 2020

\begin{abstract}
The decay of organic matter of anthropogenic origin in a highly contaminated shallow groundwater system occurs permanently regardless of the availability of oxygen. Oxidation of organic matter smoothly changes from aerobic to anaerobic and vice versa. Hydrogeochemical transformations occurring in the interior of the contaminant plume are conditioned by the position in the 3D zone of the so-called "redox reactor" and its edge. The primary reaction initiating the decay of organic matter (TOC $\max 1620 \mathrm{mg} / \mathrm{L}$, phenol $\max 613 \mathrm{mg} / \mathrm{L}$ ) is its aerobic oxidation. In the case of the consumption of free oxygen, the decay undergoes anaerobic oxidation, where the source of electrons are oxides and hydroxides $\left(\mathrm{MnO}_{2}, \mathrm{Fe}(\mathrm{OH})_{3}\right)$. As a result of these reactions, mobile ions $\mathrm{Mn}^{2+}$ and $\mathrm{Fe}^{2+}$ pass into the aqueous environment creating a concentration anomaly (max $15 \mathrm{mg} / \mathrm{L}$ for $\mathrm{Mn}^{2+}, 673 \mathrm{mg} / \mathrm{L}$ for $\mathrm{Fe}^{2+}$ ). The presence of $\mathrm{Fe}^{2+}$ in groundwater is crucial. A strong correlation between the organic matter decay processes and concentration of the $\mathrm{Fe}^{2+}$ showed that "iron index" may be a preliminary marker for the hydrogeochemical recognition of aquifer and allows to diagnose zones with an intense organic matter decay, especially by anaerobic oxidation through redox reactions. At the edge of the "redox reactor" redox sensitive metals $\left(\mathrm{Fe}^{2+}, \mathrm{Mn}^{2+}\right.$ and also $\mathrm{Cu}^{2+}, \mathrm{Cr}^{3+}, \mathrm{Hg}^{2+}$ ) undergo aerobic oxidation due to the access of oxygen as a result of mixing of contaminated groundwater and oxygenated pure Quaternary water. These transformations produce oxides and hydroxides $\left(\mathrm{MnO}_{2}, \mathrm{Fe}(\mathrm{OH})_{3}\right)$-new reaction products, however, are used for anaerobic oxidation of organic matter. Organic matter decay is an cyclic system of redox processes up to the full decay of pollutants and generation of the anomalously high concentrations of redox sensitive metals in the ground.
\end{abstract}

Keywords Organic matter decay · Iron index $\cdot$ IE index $\cdot$ IOMADI index $\cdot$ Redox processes $\cdot$ Hydrogeochemical anomaly Redox-sensitive elements · "Zachem" Chemical Plant

\section{Introduction}

European cities are constantly struggling to acquire new areas for investment and development. The answer to these needs is remediation and reclamation of degraded and heavily transformed areas. Furthermore, brownfield lands are suspected to be present on nearly every continent of the

Dorota Pierri

pierri@agh.edu.pl

Mariusz Czop

mariucz@agh.edu.pl

1 Department of Hydrogeology and Engineering Geology, AGH University of Science and Technology, 30 A. Mickiewicz Av, 30059 Krakow, Poland globe, with the greatest prevalence in post-industrial zones, i.e. places where industry boomed in the nineteenth or twentieth century and has since waned (Hollander et al. 2010). In economic terms, these areas are very valuable to obtain, but they are often accompanied by strong contamination of the environment, of soil and groundwater in particular. The key to designing effective and adequate remediation techniques is to correctly identify the hydrogeochemical conditions and transformations of pollutants in the environment.

Accurate recognition of the behaviour of pollutants in the ground and water environment is particularly important in relation to a wide range of organic compounds which, according to EEA data, constitute soil and groundwater pollution in $60-70 \%$ of the identified contaminated areas (brownfields). In light of analysis carried out in 2011, which unfortunately does not take into account several European 
countries including Poland, up to 2.5 million potentially polluted areas were identified in Europe, 342,000 pollution cases were confirmed by tests, whilst remediation or other corrective actions were carried out for approximately 51.3 thousand areas (15\% of confirmed cases) (EEA 2014).

In this study, the dominant reaction of organic matter decay in shallow groundwater system highly contaminated with co-existing inorganic and organic substances was investigated. Discharge of pollutant load to the shallow Quaternary aquifer started in the 1940s with the deposition of industrial (including hazardous) waste originating from the chemical production at the landfill site, which continued with varying intensity until 2014. It is estimated that from the beginning of the exploitation of the area until the bankruptcy of the "Zachem" Chemical Plant, a total of $300,000 \mathrm{~m}^{3}$ of chemical waste was deposited at this one landfill. Analyses of the morphology of the "Zielona" landfill body showed the deposition of phenolic pitch from the phenol and Rezokol glue production, which included phenolic sodium sulphite, as well as waste from the production of dyes and dyeing intermediates. Tarry waste, heavy oil and post-production tar was also found in the landfill bottom. Hazardous waste from special production (waste nitro compounds) was also stored there, as well as equipment and gum fittings were burnt in the part created as a combustion site. There are also visible traces of waste from the production of fungicides (chlorophenols) and from heat exchangers or raw material waste (glycols) (based on unpublished internal documents of Chemical Plant; Pietrucin 2015).
Migration of pollutants from the landfill increases the contaminant plume and contamination of subsequent surfaces. The spread of pollution started to directly threaten the nearby local community, which initiated the start of the project and detailed field studies. The specific aims of this study is to (i) diagnose hydrogeochemical transformations between organic and inorganic substances in the shallow aquifer, and (ii) explain the anomaly of concentrations of redox-sensitive metals. An important element of the project is also the search for auxiliary tools for the identification of zones of occurrence of organic pollutants, based on simple and relatively cheap chemical composition tests. Since due to the presence of non-specific organic substances in the impact zone of the former "Zachem" Chemical Plant, the costs of their detailed determinations in the tested groundwater samples are very high.

\section{Material and methods}

\section{Study area description}

Long-term and complex chemical production carried out at the "Zachem" Chemical Plant in Bydgoszcz city (Fig. 1), from the 1940s until 2014, led to pollution of the soil and water environment in an area of even $40-50 \mathrm{~km}^{2}$. The lack of legal and environmental regulations until 1979-1980 led to the penetration of a wide range of pollutants, primarily highly toxic organic compounds, into the soils, grounds, and
Fig. 1 Site plan with the location of the "Zielona" industrial waste site and accompanying groundwater contaminant plume on the groundwater table contour map

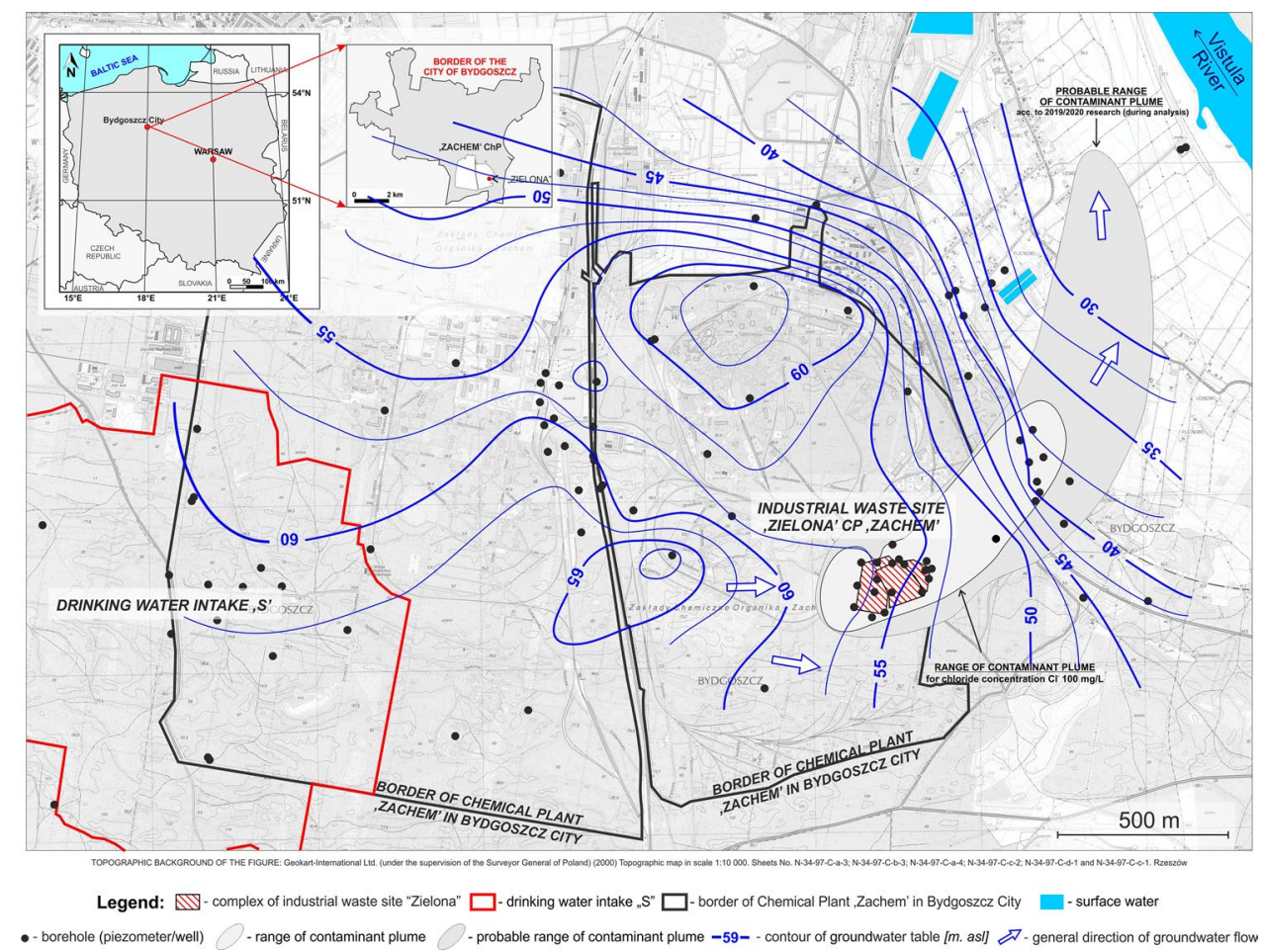


surface and groundwaters. The strongest environmental pollution occurred in the area of the "Zielona" industrial waste landfill complex (Fig. 1), which has an area of approximately 11.3 ha and has had hundreds of thousands of tonnes of hazardous waste deposited, unfortunately without any protection, i.e. without proper insulation of the surface of the waste mound, without any bottom isolation, and with the absence of any leachate capture system or even a proper environmental monitoring system.

The main organic pollutants associated with the "Zielona" landfill, identified in the contaminated groundwaters are: AOX - adsorbable organic halogen compounds (max $5.38 \mathrm{mg} / \mathrm{L}$, avg. $3.03 \mathrm{mg} / \mathrm{L}$, marked as a sum), phenol (max $613 \mathrm{mg} / \mathrm{L}$, avg. $81 \mathrm{mg} / \mathrm{L}$ ), octylphenols and octylphenoloxyethylene esters ( $\max 1.8 \mathrm{mg} / \mathrm{L}$, avg. $1.07 \mathrm{mg} / \mathrm{L}$, marked as a sum), diphenylsulfone ( $\max 1.63 \mathrm{mg} / \mathrm{L}$, avg. $0.168 \mathrm{mg} / \mathrm{L}$ ), aniline $(\max 1.92 \mathrm{mg} / \mathrm{L})$ and toluidine $(\max 7.99 \mathrm{mg} / \mathrm{L})$, hydroxybiphenyls ( $\max 92 \mathrm{mg} / \mathrm{L}$, avg. $11.27 \mathrm{mg} / \mathrm{L}$ ), PAHspolycyclic aromatic hydrocarbons, and organochlorine compounds (TCE, DCE, etc.).

There are favourable conditions in the studied area for a number of complex chemical reactions, including oxidation (decomposition) of organic matter in the groundwaters. Organic compounds migrating in the aquatic environment come from the industrial waste landfill (primary substances) but at the same time as a result of chemical reactions with other compounds (inorganic and organic) occurring within the contaminant plume, which are undergoing transformation. Therefore, new organic compounds (secondary substances) may form in the stream of contaminated groundwaters. Due to the diverse chemical composition of individual pollutant streams and different $\mathrm{pH}-\mathrm{Eh}$ conditions, the chemical reactions of both decay and the formation of new compounds can take place in different directions, leading to a wide spectrum of products. Understanding all the hydrochemical changes, however, has its origin in understanding the geological and hydrogeological conditions that determine the direction of all processes.

Currently, the area of the industrial waste landfill site is excluded from use. The topography is mostly flat, with surface elevations of 58-65 m above sea level. The shallow geology is dominated by a thick succession of Quaternary glaciofluvial deposits (sands and clays) down to a depth of around $40 \mathrm{~m}$.

In the region of the landfill, Quaternary aquifers associated with fluvioglacial fine- and medium-grained sands, as well as gravels, occur in the hollow of low-permeable underlying formations. The groundwater table usually has an unconfined nature, but locally there are also thrust conditions, and the flow directions are partly determined by the presence of lenses of poorly permeable formations and the morphology of the underlying glacial tills' ceiling. Based on head measurements in the monitoring wells and hydrogeological numeric modelling, the general direction of groundwater flow is toward the north-east into the Vistula River (Fig. 1). The unconfined groundwater table at the location varies seasonally and/or depends on the degree of filling of the western complex of a waste landfill site reaching an average depth of about $5 \mathrm{~m}$ below the ground level. The thickness of the aquifer in the Quaternary sands around the landfill reaches several or over a dozen meters. The filtration factor of these formations is within the range of $4.0 \times 10^{-5}$ to $1.7 \times 10^{-4} \mathrm{~m} / \mathrm{s}$ (Narwojsz 1989, 2007; Smarzyński and Sadowski 2005). The studied area is under very strong influence of the Vistula River drainage, which is situated approximately $3 \mathrm{~km}$ away. The terrain surface is inclined towards the riverbed, with surface elevations of 38-45 $\mathrm{m}$ above sea level. Contaminated groundwater migrating into the Vistula River Valley runs in the surficial layer of sandy soil but often reveals on the surface.

The elements disturbing the natural directions of groundwater flow in the area of the landfill were: the liquidated barrier intake and the cut-off wall located north-east of the landfill. The main drawback in the operation of the barrier intake was the drainage of water from early April to midNovember, with a break for the winter season. As a result, in the remaining months (from early December to late March), pollution whose migration was intensified in connection with the functioning of the intake had unlimited possibility of moving towards the Vistula River. Another mistake in the operation of the barrier intake was the successive limitation of the amount of water being pumped out to about $1 / 3$ of the initial value (i.e. below $40-50$ thousand $\mathrm{m}^{3}$ ) and shutting off two of the three barrier wells (i.e. wells $B$ and $A_{1}$-marked in Fig. 2). For these reasons, the barrier of interception wells has not fulfilled its task, which was to stop the migration of contaminated groundwater from the "Zielona" landfill towards the Vistula River (Czop and Pietrucin 2017; Pierri et al. 2017).

In 2003, due to unsatisfactory effects of the barrier intake, a drainage system was made along the eastern edge of the landfill within the Plant, and a tight cut-off wall (marked in Fig. 2) was installed, which was to prevent the migration of contaminated groundwater outside the Plant. Monitoring tests carried out in the observation boreholes located behind the wall, in the direction of groundwater outflow, have proven that the installation does not meet its purpose. Pollution is still migrating to the north-east, suggesting that the wall probably has not been deepened to the glacial till ceiling and is not, therefore, an effective barrier to the flow of pollutants. An additional disadvantage of the installation was the shutting down, in the final phase of its operation, of the pumping station of polluted water discharging wastewater from the drainage system into the company's sewage system. In such a system, the dammed stream of polluted waters gained the possibility of flowing around the wall. 


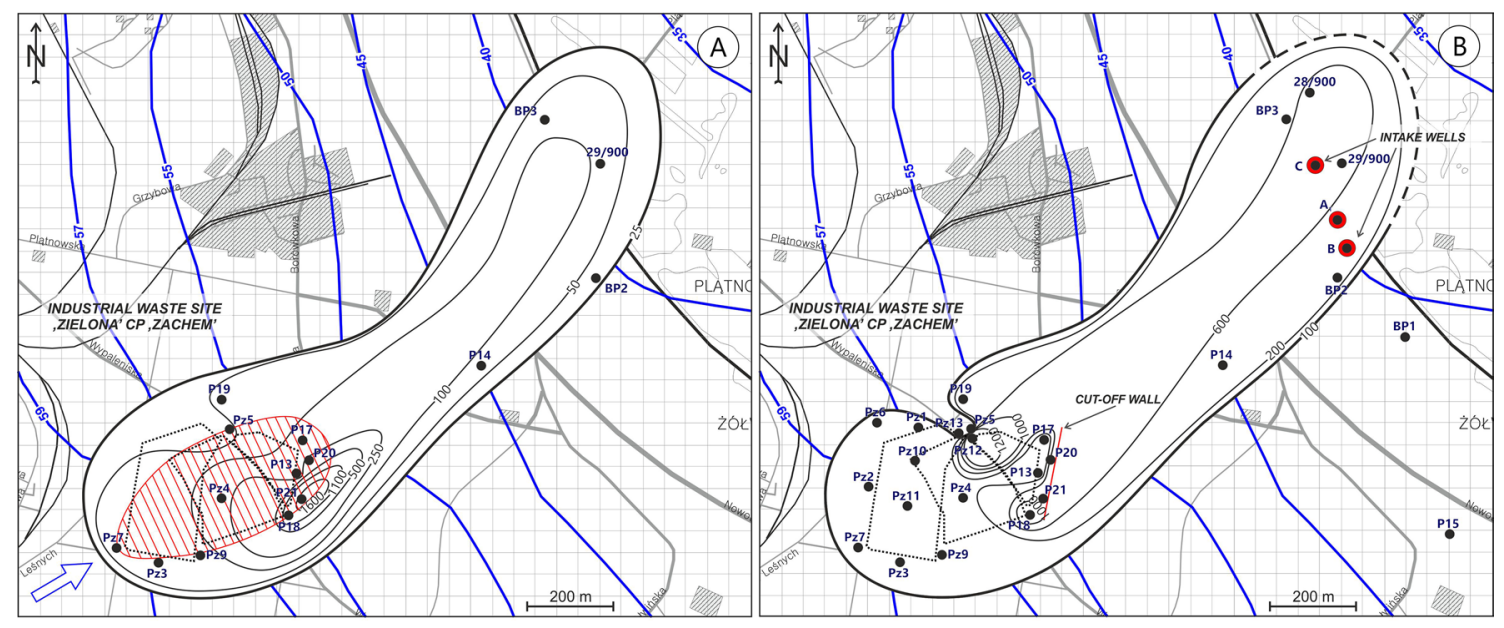

Legend: :...:- complex of industrial waste site "Zilona" Pzä

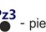

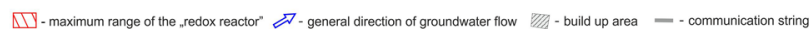

Fig. 2 Distribution of: (a) TOC and (b) $\mathrm{HCO}_{3}{ }^{-}$concentrations $[\mathrm{mg} / \mathrm{L}]$ in Quaternary groundwater in the area of industrial waste landfill

All measures implemented at the Plant to reduce and/or stop the migration of pollutants from the "Zielona" landfill were thoughtless and erroneous and not only failed to prevent contamination but even indirectly contributed to the formation of an extensive contaminant plume, whose front is located at a distance of about $1.0-1.2 \mathrm{~km}$ from the source. It should be mentioned here that the latest hydrogeochemical studies carried out in the years 2019-2020, based inter alia on the use of the "iron index", indicate that the range of the contaminant plume is much larger, and its front is at a distance of even $2.5-3 \mathrm{~km}$ from the landfill (Fig. 1).

\section{Hydrochemical measurement}

The monitoring network of the soil and water environment at the landfill includes 25 piezometers and 3 wells. During the field studies, in situ measurements of physicochemical parameters of groundwater (Eh, EC, $\mathrm{pH}, \mathrm{T}$ ) were carried out with the frequency of every $50 \mathrm{~cm}$ of water column in the well. As a result of detection of a strong stratification of pollutants, samples for the analysis of the efficiency of organic matter decay were collected from all points by using the "low flow" technique from the bottom part of the borehole, characterized by the highest concentrations of chemical substances (Pietrucin 2013). It should be noted that the monitoring network of the plant was designed in the 1980s and is characterized by a strong density around the landfill, the lack of points on the fetch of the contaminant plume and subsequent boreholes on the front of the plume.

In accredited hydrogeochemical laboratories, a full range of inorganic substances and selected organic substances were determined, including TOC (non-dispersive infrared detection method (NDIR)-PN-EN 1484:1999), phenol index (4-aminoantipyrine spectrometric method after distillation-PN ISO 6439:1994), $\mathrm{H}_{2} \mathrm{~S}$ (thiomercurimetric method-PN-C-04566.03:1982), $\mathrm{HCO}_{3}{ }^{-}$(titration), minor elements $\mathrm{Fe}^{2+}, \mathrm{Mn}^{2+}, \mathrm{Cu}^{2+}, \mathrm{Cr}^{3+}$ and $\mathrm{Hg}^{2+}$ (inductively coupled plasma-mass spectrometry (ICP-MS) - PN-EN ISO 17294-1:2007; PN-EN ISO 17294-2:2006) and macro elements (inductively coupled plasma optical emission spectrometry (ICP-OES)—PN-EN ISO 11885:2009).

The assessment of the degree of pollution of the Quaternary groundwater in the area of the "Zielona" industrial waste landfill was referred to the hydrogeochemical background value determined for the entire area of the Chemical Plant. The hydrogeochemical background was determined on the basis of water sampling in the " $\mathrm{S}$ " water intake zone and its monitoring network, i.e. in the holes located in the groundwater inflow zone. Hydrogeochemical tests covered 12 holes: 5 wells and 7 piezometers. Due to the stability of the chemical composition of the intake waters, the sampling was one-off. The water intake is under constant control of the District Sanitary and Epidemiological Station in Bydgoszcz city, and the water used is suitable for consumption without the need for iron and manganese removal.

\section{Results}

The aquifer is composed of fluvioglacial and aeolian sands lacking natural organic matter $(\mathrm{NOM}<1 \%$ (Pietrucin 2015)) with an average TOC content in groundwater of $2-5 \mathrm{mg} / \mathrm{L}$. Initially, the level of groundwater contamination was expressed by the TOC parameter. It includes the sum of all organic substances present in the solution, identified both quantitatively and/or qualitatively as well as substances not disclosed in 
previous studies. The TOC parameter includes compounds derived from vegetation decay, bacterial growth, metabolic activity of living organisms, but also degradation of chemical substances. TOC is therefore provided by both the decay of natural organic matter (NOM, e.g. humic and fulvic acids, amines, urea) as well as anthropogenic sources (Hendricks 2007). In the area of industrial waste landfill organic compounds of anthropogenic origin dominate in the aquifer with the absence of NOM. They constitute waste of the chemical industry, resulting from the processes of chemical synthesis carried out under the conditions of the "Zachem" Chemical Plant (Table 1).

The aquifer is composed of sands, well-sorted, fine and medium-grained, where the characteristic diameter $\left(d_{50}\right)$ of the grains ranges from 0.15 to $0.45 \mathrm{~mm}$. In mineralogical and petrographic terms, Quaternary sands are made of quartz, in the amount of about $80-90 \%$, additionally, there are feldspars within them - up to about $10-15 \%$, and limestone up to about 4-5\%. Heavy minerals occur in the sands in small amounts up to $1 \%$ by weight and are represented by amphiboles, garnets, biotite, and pyroxenes with significant variability of percentage (Weckwerth and Chabowski 2013). Within the Quaternary sands, there are no minerals that are an important source of iron, where it usually occurs at levels of up to about $2-10 \mathrm{~g} / \mathrm{kg}$. The iron content expressed as $\mathrm{Fe}_{2} \mathrm{O}_{3}$-iron oxide in the tested sand samples, is usually around $1.5-2.2 \%$, while for $\mathrm{MnO}-$

\section{Discussion: hydrogeochemical processes within the contaminated aquifer}

The chemical composition of groundwater in the area of the "Zielona" landfill is formed by hydrogeochemical processes occurring within the contaminant plume. During detailed hydrochemical tests of the contaminated groundwater, a number of chemical processes were diagnosed, including: (i) decomposition of organic matter under the conditions of availability and lack of oxygen, (ii) dehalogenation, (iii) denitrification and desulphurization, and (iv) specific decay of so-called characteristic organic compounds such as phenol, aniline, and toluidine. Strong diversity of chemical species of elements was also found (Pietrucin 2015). The main process that has a decisive impact on the chemical composition of the examined waters and the degree of pollution of the soil and water environment is the decay of polluting chemicals.

\section{Initial aerobic organic matter decay}

It is correctly assumed that in shallow Quaternary aquifer the aerobic decay of organic matter is the predominant hydrogeochemical reaction. This is due to the ease of obtaining dissolved $\mathrm{O}_{2}$ from the highly oxygenated environment. According to the theory, this reaction takes the form of a classic formula:

$\mathrm{CH}_{2} \mathrm{O}+\mathrm{O}_{2} \leftrightarrow \mathrm{CO}_{2(\mathrm{~g})} \uparrow+\mathrm{H}_{2} \mathrm{O} \leftrightarrow \mathrm{H}_{2} \mathrm{CO}_{3} \leftrightarrow \mathrm{H}^{+}+\mathrm{HCO}_{3}^{-} \leftrightarrow \mathrm{CO}_{3}^{2-}+\mathrm{H}^{+}$

(all organic substances schematically represented in the form of formaldehyde $\mathrm{CH}_{2} \mathrm{O}$ ).

manganese oxide, it is only around $0.02-0.4 \%$. These sandy formations are also poor in organic matter, which is found in quantities of only about $2-11 \mathrm{~g} / \mathrm{kg}$, i.e. about $0.2-1.1 \%$ (Jankowski 2014).

The natural non-contaminated composition of Quaternary groundwater is $\mathrm{Ca}-\mathrm{HCO}_{3}$. Water mineralization is $242-406 \mathrm{mg} / \mathrm{L}$, with an arithmetic average of $353 \mathrm{mg} / \mathrm{L}$. The concentrations of dominant ions are $42-79 \mathrm{mg} / \mathrm{L}$ for calcium and $165-254 \mathrm{mg} / \mathrm{L}$ for bicarbonate (Table 2). A very important aspect concerning the subject of this paper is iron and manganese concentrations. These elements are present in water at an average concentration level of $0.089 \mathrm{mg} / \mathrm{L}$ for iron and $0.025 \mathrm{mg} / \mathrm{L}$ for manganese. Therefore, iron and manganese concentrations meet drinking water standards, amounting in Poland and the EU to $0.2 \mathrm{mg} / \mathrm{L}$ and $0.05 \mathrm{mg} / \mathrm{L}$, respectively, despite the fact that, generally, Quaternary groundwater in the region of Kujavia (northern Poland) is characterized by geogenically increased values of these elements. The $\mathrm{pH}$ of the water is slightly alkaline (pH 7.72-8.25) and it has Eh values between +61 and $+232 \mathrm{mV}$.
The proof of the correctness of this reaction in the immediate vicinity of the pollution source is the assessment of the efficiency of organic matter decay based on the analysis of the occurrence of TOC and $\mathrm{HCO}_{3}{ }^{-}$in groundwater (Fig. 2). High concentrations of TOC ( $\max 1620 \mathrm{mg} / \mathrm{L})$ were identified in the entire impact zone of the industrial waste landfill, i.e. within the contaminant plume. A very similar distribution of concentrations is found for bicarbonate ions $\mathrm{HCO}_{3}{ }^{-}$(max $1089 \mathrm{mg} / \mathrm{L}$ ) (Pietrucin 2015).

In the presence of oxygen in the soil and water environment the primary aerobic decay of organic compounds is initiated in the area of the landfill (Hammes and Verstraete 2002; Peng et al. 1993; Kristensen et al. 1995). The course of the above hydrogeochemical process is confirmed by the relationship of the concentrations of $\mathrm{HCO}_{3}{ }^{-}$and TOC in the analyzed waters (Fig. 3).

The aerobic oxidation of organic matter leads to the complete utilization of oxygen available in the dissolved form in shallow Quaternary groundwater. In such case oxygen incorporated in the structure of anions from sulphates 


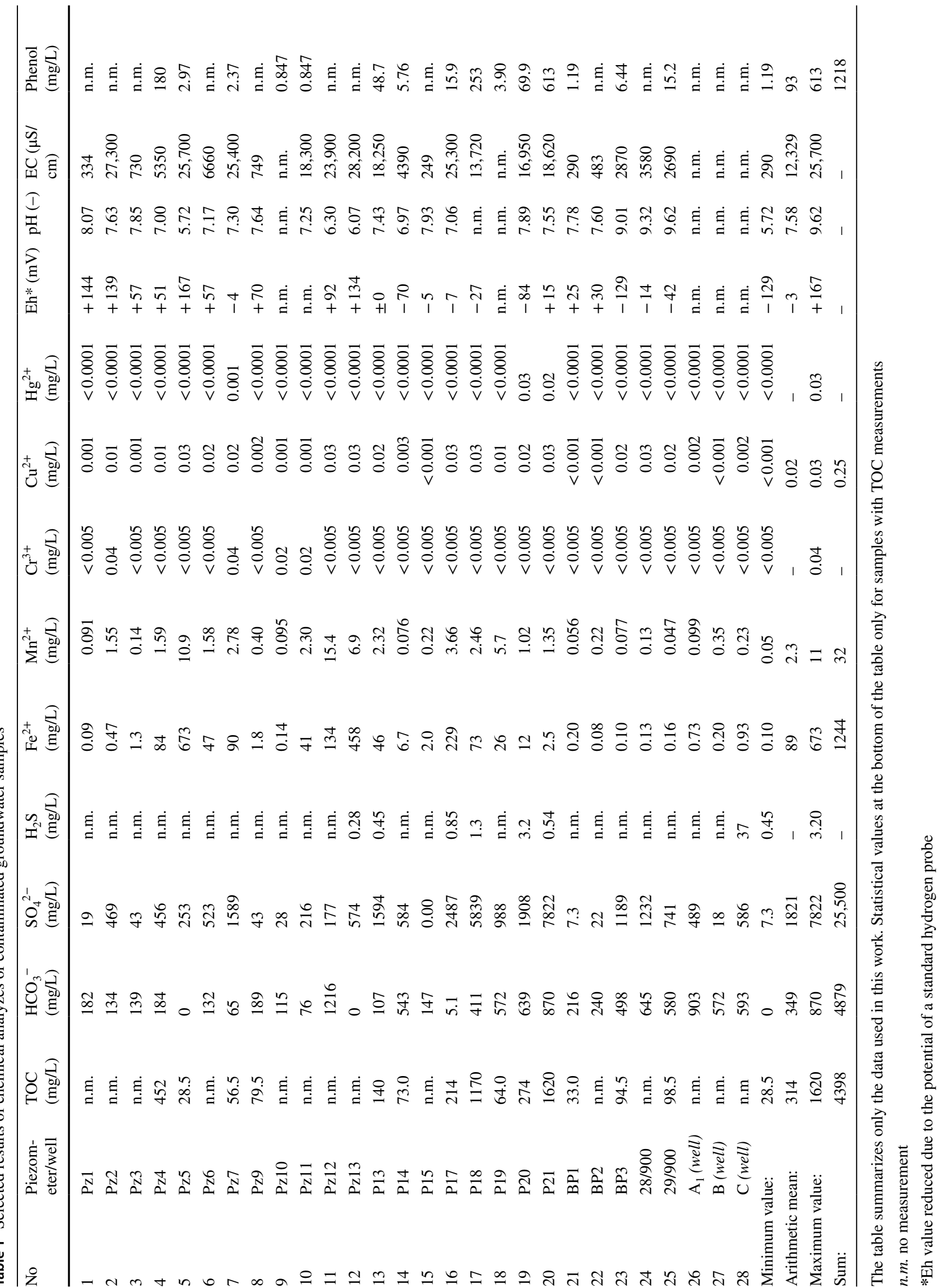




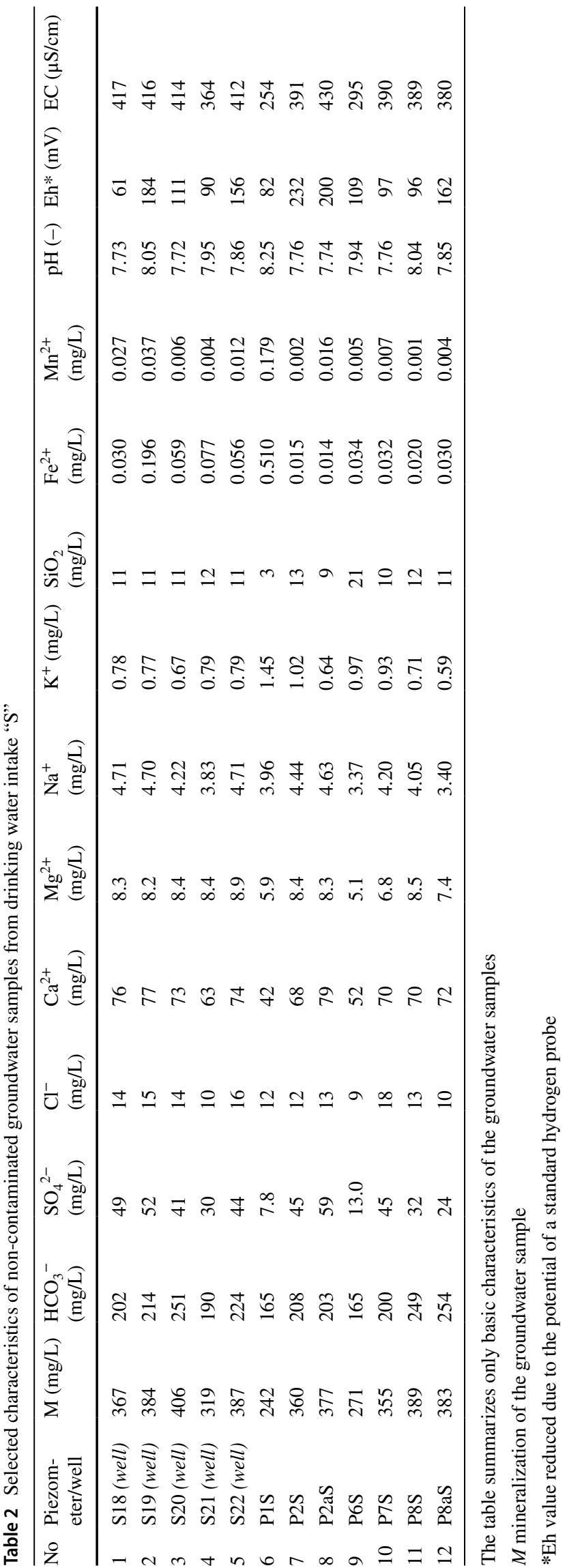

$\mathrm{SO}_{4}{ }^{2-}$ ( $\max 7822 \mathrm{mg} / \mathrm{L}$ ) is used for further decay reactions. Field studies revealed the presence of a dissimilatory desulfurization, which can be described by the following scheme $\mathrm{SO}_{4}{ }^{2-} \rightarrow \mathrm{SO}_{3}{ }^{2-} \rightarrow \mathrm{S}_{3} \mathrm{O}_{6}{ }^{2-} \rightarrow \mathrm{S}_{2} \mathrm{O}_{3}{ }^{2-} \rightarrow \mathrm{S}^{0} \rightarrow \mathrm{H}_{2} \mathrm{~S}$, where hydrogen sulphide gas, released into the atmosphere, is the final product:

$$
\begin{aligned}
& \mathrm{CH}_{2} \mathrm{O}+\mathrm{SO}_{4}^{2-}+5 \mathrm{H}^{+} \rightarrow \mathrm{HS}^{-}+\mathrm{CO}_{2}+3 \mathrm{H}_{2} \mathrm{O}, \\
& \mathrm{CH}_{2} \mathrm{O}+\mathrm{SO}_{4}^{2-}+3 \mathrm{H}^{+} \rightarrow \mathrm{H}_{2} \mathrm{~S}_{(\mathrm{g})} \uparrow+\mathrm{CO}_{2}+3 \mathrm{H}_{2} \mathrm{O} .
\end{aligned}
$$

The presence of hydrogen sulphide in groundwater was confirmed in six piezometers (Pz13, P13, P17, P18, P20, and P21) where its concentrations were determined within 0.28-3.2 $\mathrm{mg} / \mathrm{L}$. In well C, the concentration of hydrogen sulphide was definitely higher, reaching a level of $37 \mathrm{mg} / \mathrm{L}$.

In the presence of high organic matter content, the assimilative denitrification process involves the reduction of nitrates to amines of the general formula $\mathrm{R}-\mathrm{NH}_{2}(\mathrm{R}-$ monovalent functional group). The final process of reduction of nitrogen speciation is ammonification $\mathrm{R}-\mathrm{NH}_{2} \rightarrow \mathrm{NH}_{4}^{+}$. The probability of assimilative denitrification is high due to the lack of $\mathrm{NO}_{3}{ }^{-}(<0.5 \mathrm{mg} / \mathrm{L})$ and $\mathrm{NO}_{2}{ }^{-}(<0.02 \mathrm{mg} / \mathrm{L})$, with the simultaneous presence in groundwater of nitrogen organic compounds used in the production of dyes: chloroaniline $\mathrm{ClC}_{6} \mathrm{H}_{4}-\mathrm{NH}_{2}(\max 0.37 \mathrm{mg} / \mathrm{L}$ in piezometer $\mathrm{P} 17)$, aniline $\mathrm{C}_{6} \mathrm{H}_{5}-\mathrm{NH}_{2}(\max 1.92 \mathrm{mg} / \mathrm{L}$ in $\mathrm{P} 21)$ and toluidine $\mathrm{CH}_{3} \mathrm{C}_{6} \mathrm{H}_{4}-\mathrm{NH}_{2}(\max 7.99 \mathrm{mg} / \mathrm{L}$ in P21). Only in one Pz1 piezometer, nitrates $\left(\mathrm{NO}_{3}\right)$ are present in concentrations above the limit of quantification, i.e. $1.40 \mathrm{mg} / \mathrm{L}$.

An additional, intermediate environmental effect of the initial aerobic decay of organic matter is the variation in the $\mathrm{pH}$ of groundwater (Fig. 4). The carbonic acid $\mathrm{H}_{2} \mathrm{CO}_{3}$ is a weak diprotic acid which most strongly dissociates at degree I, i.e. to the production of $\mathrm{HCO}_{3}{ }^{-}$. Water analyses indicate zones with low $\mathrm{HCO}_{3}{ }^{-}$content or even lack thereof. Generally, under the conditions of oxidation of organic substances, $\mathrm{H}^{+}$hydrogen ions are released and the environment is acidified to $\mathrm{pH}$ of approximately $5-6$ ( $\mathrm{min}$. $\mathrm{pH} 5.72$ ). The hydrogen $\left(\mathrm{H}^{+}\right)$ions, released under the organic matter decay conditions may react: (1) with carbonate minerals (e.g. calcite scattered in the Quaternary deposits), (2) with silica $\mathrm{SiO}_{2}$, or (3) undergo adsorption on quartz grains (Rashkeev et al. 2001, 2002; Kutsuki et al. 2007; Sah 1996). The $\mathrm{HCO}_{3}{ }^{-}$ion is the predominant species in the $\mathrm{pH}$ range of 6-8, while at low and high $\mathrm{pH}$ its concentrations are reduced. In the northeast direction groundwater turns into neutral and slightly alkaline $\mathrm{pH}$ and the highest $\mathrm{pH}$ values are recorded on the front of the contaminant plume ( $\max \mathrm{pH} 9.93)$.

The launch of the aerobic oxidation process of dissolved organic matter is a factor initiating the possibility of cyclic redox processes that additionally take place with the active participation of many specialised populations of bacterial 
Fig. 3 Concentration dependence of TOC and $\mathrm{HCO}_{3}{ }^{-}$in Quaternary groundwater in the area of industrial waste landfill
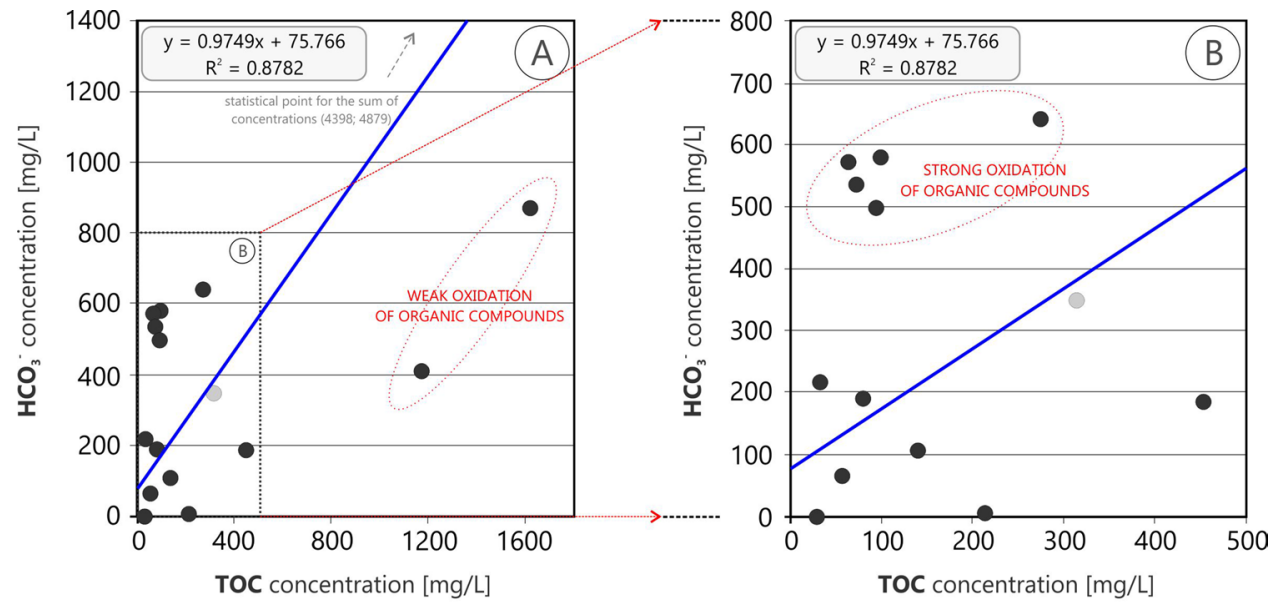

- measurement data - statistical point for mean concentrations $(314 ; 349)$

organisms, both oxidising and reducing (Borch et al. 2010). These organisms support the chemical processes that take place and provide substrates for new reactions to occur, but under typical conditions they are of secondary importance. The framework of the processes taking place is determined to the greatest extent by chemical and environmental conditions (pH-Eh), in which specialised bacterial populations fit in and adapt them to their needs to some extent.

Aerobic oxidation of organic matter leads to the complete utilization of oxygen available in the dissolved form in shallow, Quaternary groundwater and/or incorporated in the anion structure. In the case of inflow of increased pollutant load (excess of organic matter) there is a possibility of initiation of the secondary anaerobic oxidation of organic matter. The classic form of aerobic oxidation of organic mat- matter. The further course of anaerobic decay requires the acquisition of electrons necessary for the oxidation of organic substances from a source other than oxygen atoms. The electron donors are primarily redox sensitive metal atoms at high oxidation states, which are bound in the form of oxides and hydroxides. These are mainly $\mathrm{MnO}_{2}$ or $\mathrm{Fe}(\mathrm{OH})_{3}$ originally present in the Quaternary rock matrix, as well as $\mathrm{Cr}(\mathrm{OH})_{3}$ or $\mathrm{CuFe}_{2} \mathrm{O}_{4}$ (Weiner 2008; Schout et al. 2017). These compounds may also be re-created in the environment of the landfill in the process of oxidation of organic substances under conditions of oxygen availability. The reduction products of manganese and iron oxides and hydroxides $\left(\mathrm{MnO}_{2}, \mathrm{Fe}(\mathrm{OH})_{3}\right)$ are $\mathrm{Mn}^{2+}$ and $\mathrm{Fe}^{2+}$ and this reaction is such strong that anomalous concentrations of these metals are created (Fig. 5). The reaction proceeds according to the following formula (Liebes 2009):

$2 \mathrm{CH}_{2} \mathrm{O}+2.5 \mathrm{MnO}_{2(\mathrm{~s})} \downarrow+2 \mathrm{H}^{+} \rightarrow 2 \mathrm{CO}_{2(\mathrm{~g})} \uparrow+2.5 \mathrm{Mn}^{2+}+3 \mathrm{H}_{2} \mathrm{O}$

$\mathrm{CH}_{2} \mathrm{O}+3 \mathrm{Fe}(\mathrm{OH})_{3(\mathrm{~s})} \downarrow+5 \mathrm{H}^{+} \rightarrow \mathrm{CO}_{2(\mathrm{~g})} \uparrow+3 \mathrm{Fe}^{2+}+8 \mathrm{H}_{2} \mathrm{O}$

(anaerobic decay of organic matter with simultaneous reduction of inorganic manganese and iron compounds).

ter is therefore only the form of initiation of the matter decay process. Moreover, within the boundaries of the "Zielona" industrial landfill body and in its immediate vicinity, specific hydrogeochemical conditions are created-a "redox reactor", whose range falls within the boundaries of the contact between water heavily contaminated with organic compounds and natural Quaternary groundwater, saturated with oxygen from atmospheric air.

\section{Anomaly of redox sensitive metal concentrations}

Lack of availability of oxygen in the soil and groundwater environment is not a barrier to the further decay of organic
Within the boundaries of the "redox reactor", metals are rapidly released to groundwater. The unusually high concentrations of redox sensitive metals were observed at the level of $\max 15 \mathrm{mg} / \mathrm{L}$ for manganese and $673 \mathrm{mg} / \mathrm{L}$ for iron. Also the following metals: $\mathrm{Cr}^{3+}(\max 0.0427 \mathrm{mg} / \mathrm{L}), \mathrm{Cu}^{2+}$ $(\max 0.0337 \mathrm{mg} / \mathrm{L})$ and $\mathrm{Hg}^{2+}(\max 0.0245 \mathrm{mg} / \mathrm{L})$ appear in the environment. These metals change their oxidation state under normal environmental conditions (structure of the electron shell), which results in changes in solubility due to the formation of new compounds during the reaction with water. 


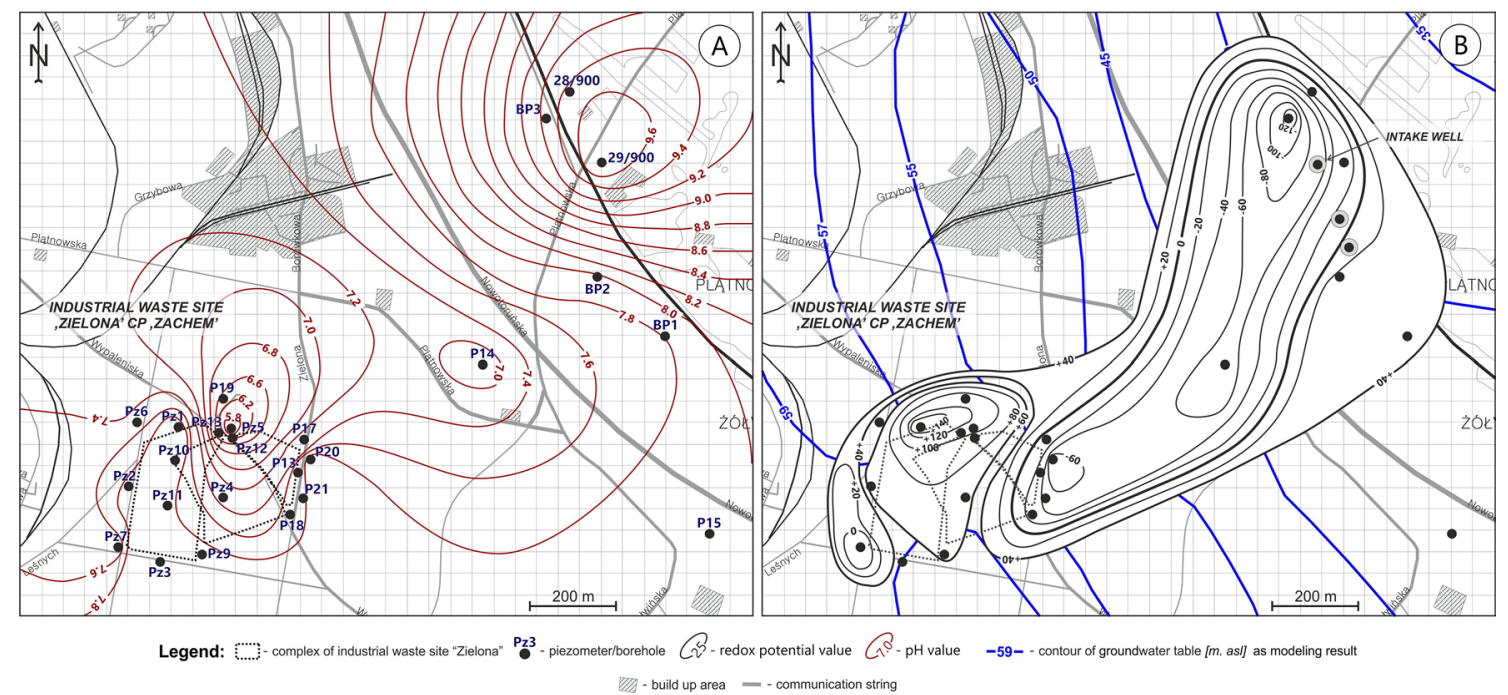

Fig. 4 Distribution of: (a) pH and (b) Eh value $[\mathrm{mV}]$ in Quaternary groundwater in the area of industrial waste landfill

Under aerobic conditions, concentrations of iron dissolved in the solution are limited by the precipitation of insoluble $\mathrm{Fe}(\mathrm{OH})_{3}$. On the other hand, under reducing conditions and $\mathrm{pH}$ lower than 7.0, and lack of sulphates $\mathrm{SO}_{4}{ }^{2-}$ in groundwater, iron occurs in the form of a soluble $\mathrm{Fe}^{2+}$ cation. Above $\mathrm{pH} 7.0$ one can find $\mathrm{Fe}(\mathrm{OH})_{2}$, which is $10^{5}$ times more soluble than $\mathrm{Fe}(\mathrm{OH})_{3}$. The other sensitive metals behave similarly under reducing conditions, occurring in the form of a soluble cation or relatively soluble compound (Weiner 2008). The concentrations of manganese determined in groundwater show analogous distribution to iron.

In the contaminant plume, $\mathrm{Mn}^{2+}, \mathrm{Fe}^{2+}, \mathrm{Cr}^{3+}, \mathrm{Cu}^{2+}$ and $\mathrm{Hg}^{2+}$ metals occur in the form of different species, and the mobility of each of them differs depending on the characteristic environmental conditions. Together with the migration of the contaminant plume, the oxidizing conditions $(+176 \mathrm{mV})$ turn into reducing conditions to the value of Eh $-129 \mathrm{mV}$. The observed change in the redox potential by more than $300 \mathrm{mV}$ occurs within one contaminant plume. The variability of the redox potential differentiates the metal solubility, because it may affect the electron structure of atoms of a given element. Solubility, next to sorption, is one of the most important properties affecting the mobility of pollutants in the environment (Weiner 2008).

The process of anaerobic oxidation of organic matter through the consumption of $\mathrm{H}^{+}$ions leads to the increase in the $\mathrm{pH}$ of the environment, with the simultaneous emission of $\mathrm{CO}_{2}$. The course of the processes also explains the low concentrations of bicarbonate ions under the conditions of reduced Eh, which prevail in the root zone of the plume, in the vicinity of the industrial waste site "Zielona".

\section{Iron index as organic matter decay intensity indicator}

Phenol is a specific contamination considered as characteristic of the "Zachem" Chemical Plant in Bydgoszcz city and directly related to the production of pure phenol and intermediate products such as phenol-formaldehyde adhesives. It is the largest part of groundwater contamination by organic substances ( $\max 40 \%$ of TOC in piezometer P17) (Fig. 6). Degradation of phenol in soil and in groundwater is strongly diversified due to the prevailing oxidation and reduction conditions (Loehr and Matthews 1992; Sinsabaugh 2010; van Schie and Young 2007). The half-life $t_{1 / 2}$ is on average up to 20 days (Vaishnav and Babeu 1987; Lerner et al. 2005). However, long-term persistence of phenol in the soil and water environment is acceptable if concentrations reach high values (ATSDR 2011). The original amount of deposited phenol in the waste landfill is significant (initially tens of thousands of tons). This means that despite a relatively short half-life, phenol will be present in groundwater in subsequent years. At present, there is an intensive process of leaching waste from a landfill.

Detailed analysis of the distribution of organic and inorganic compounds showed a strong dependence of the contaminant plume, including in particular phenol ( $\max$ $613 \mathrm{mg} / \mathrm{L}$, at geometric mean $12.21 \mathrm{mg} / \mathrm{L}$ ), in relation to the anomalies of the concentrations of redox sensitive metals especially $\mathrm{Fe}^{2+}$ and $\mathrm{Mn}^{2+}$ also sum of $\mathrm{Cr}^{3+}, \mathrm{Cu}^{2+}$ and $\mathrm{Hg}^{2+}$. As already mentioned, iron and manganese occur within fine-grained sands that build an aquifer in relatively small amounts of several to several dozen $\mathrm{g} / \mathrm{kg}$. In natural, non-contaminated groundwater, iron and manganese concentrations are usually below levels of acceptable norms for 


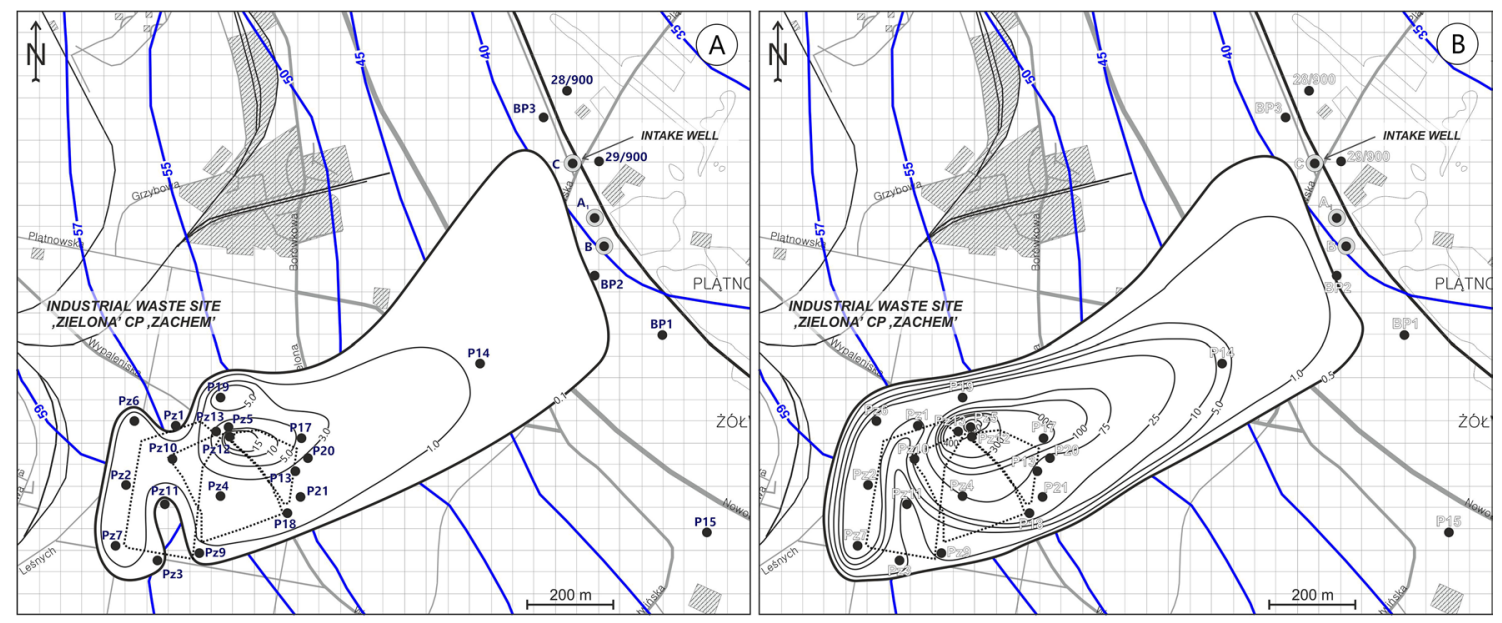

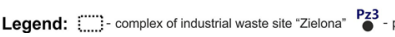

C

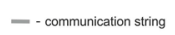

Fig. 5 Distribution of: (a) $\mathrm{Mn}^{2+}$ and (b) $\mathrm{Fe}^{2+}$ concentrations $[\mathrm{mg} / \mathrm{L}]$ in Quaternary groundwater in the area of industrial waste landfill

drinking water, which are $0.2 \mathrm{mg} / \mathrm{L}$ and $0.05 \mathrm{mg} / \mathrm{L}$, respectively. Concentrations of $\mathrm{Fe}^{2+}$ and $\mathrm{Mn}^{2+}$ ions in groundwater samples taken within the boundaries of the contaminant plume with organic compounds and phenol are extremely high, considering local geochemical conditions. Iron concentrations in organic pollution zones, mainly phenol, are extremely high and range from several dozen to several hundred $\mathrm{mg} / \mathrm{L}$. The maximum level of this ion $\left(\mathrm{Fe}^{2+}\right)$ is observed in the piezometer Pz5, where it is $673 \mathrm{mg} / \mathrm{L}$ and exceeds the level of hydrogeochemical background (about $0.2-0.5 \mathrm{mg} / \mathrm{L}$ ) by over 3300 times. Similarly, anomalously high concentrations are found in the discussed zone of the organic contaminant plume in relation to manganese ions $\left(\mathrm{Mn}^{2+}\right)$, which range from 0.05 to $11 \mathrm{mg} / \mathrm{L}$, but most often reach a level of several $\mathrm{mg} / \mathrm{L}$. The maximum concentration of $\mathrm{Mn}^{2+}$ was found in the Pz12 piezometer, where it is $15.4 \mathrm{mg} / \mathrm{L}$ and over 300 times higher than the typical value for the hydrogeochemical background. The statistical measure of correlation of iron and manganese concentrations is relatively high, where the determination coefficient $R^{2}$ is 0.785 .

This allows to combine the interpretation of the occurrence of the organic pollutants, mainly phenol and iron concentrations. In the case of certainty of organic contamination, the "iron index" may be a preliminary marker for the hydrogeochemical recognition of shallow Quaternary aquifer. A simple and inexpensive chemical analysis of contaminated groundwater allows to diagnose zones with an organic matter occurrence and associated pollution of groundwater.

Index of Iron Enrichment (IE) has the following form:

$\mathrm{IE}=\lg \frac{c_{\mathrm{Fe} 2+}}{c_{\mathrm{HB}}}$, where $c_{\mathrm{Fe} 2+}$ is the $\mathrm{Fe}^{2+}$ ion concentration in the tested water sample (in $\mathrm{mg} / \mathrm{L}$ ), $c_{\mathrm{HB}}$ is the $\mathrm{Fe}^{2+}$ ion concentration for noncontaminated groundwater (Hydrogeochemical Background) (in $\mathrm{mg} / \mathrm{L}$ ).

The highest value of the "Iron Enrichment index" was found in the group of neighbouring piezometers (Pz4, Pz5, P13, P17 and P18) located in the north-eastern part of the "Zielona" industrial waste landfill. This is an area of the most intensive course of anaerobic oxidation of organic matter, including phenols where, interestingly, a similar IE index value is recorded in the Pz7 piezometer located on the eastern border of the landfill complex. The IE index value clearly decreases in the direction of groundwater stream flow, where in piezometers P14, P20 and P21 it reaches values above 1 , and ranges between 1.1 and 1.8. The lowest IE index values are observed at the boundaries of the contaminant plume, where within the piezometer grouping on the plume front (BP1, BP3 and 29/900) it adopts negative values, i.e. iron concentrations in these holes are lower than the average value for the hydrogeochemical background (Fig. 7). A small amount of $\mathrm{Fe}^{2+}$ ions in groundwater in this region indicates that anaerobic oxidation of organic matter is most likely not present and the redox potential value is clearly more negative, which significantly hinders further degradation of organic pollutants, including phenol.

Under the conditions of the discussed organic contaminant plume, the process of anaerobic oxidation of organic compounds is so intense that it contributes to the formation of significant amounts of $\mathrm{Fe}^{2+}$ ions, so that their concentration in groundwater reaches levels from several to more than 
Fig. 6 Distribution of phenol concentrations $[\mathrm{mg} / \mathrm{L}]$ in Quaternary groundwater in the area of industrial waste landfill

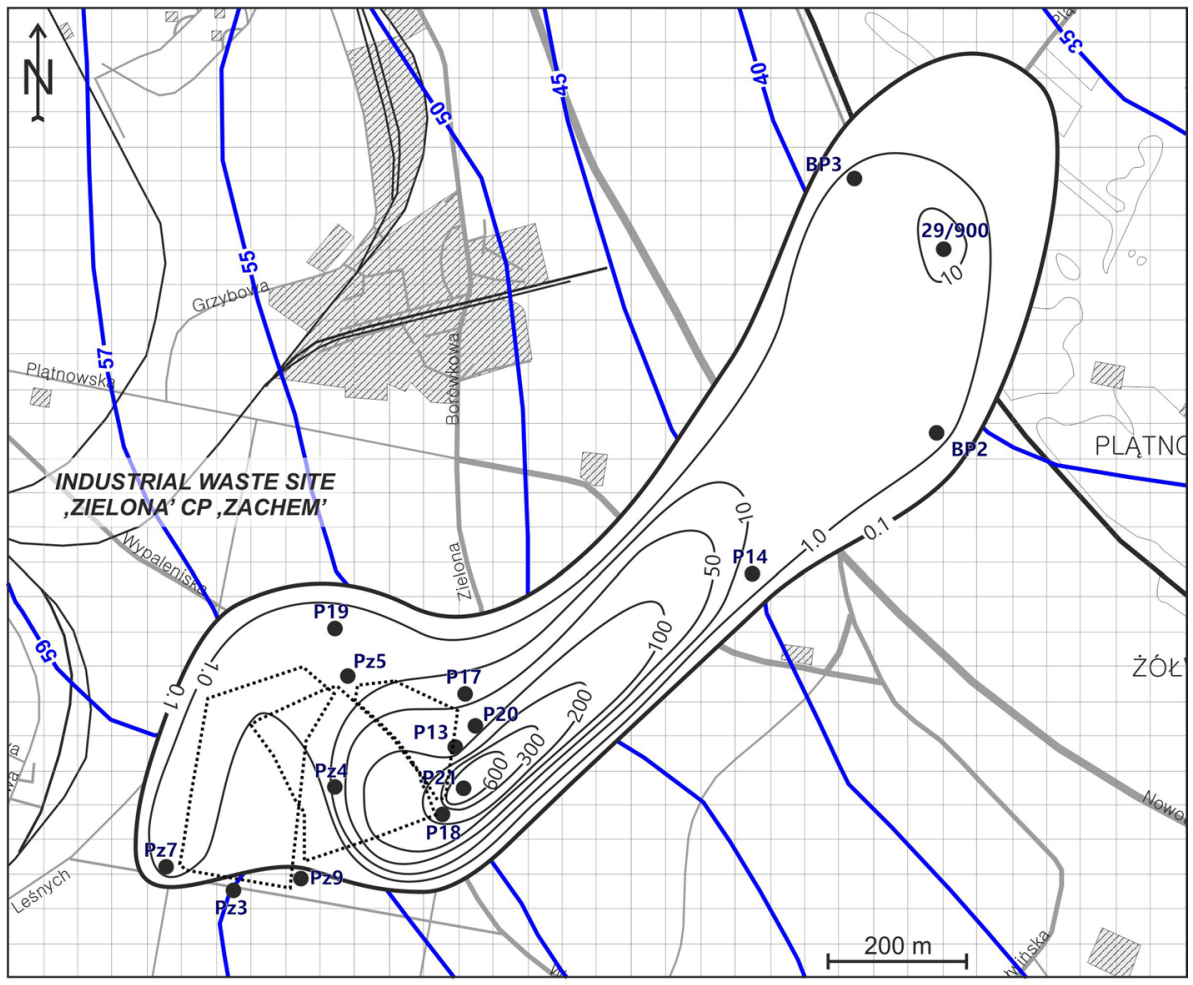

Legend: :.......- complex of industrial waste site "Zielona" Pz3 - piezometer/borehole -59- - contour of groundwater table $[\mathrm{m}$. asl] as modeling result $\quad$ - build up area $\quad-$ communication string
$10 \mathrm{mmol} / \mathrm{L}$. This gives the opportunity to assess the intensity of anaerobic oxidation of organic matter in relation to the simultaneous standard oxidation of oxygen dissolved in water. The hydrogeochemical indicator enabling this type of assessment is based on a comparison of molar concentrations of $\left[\mathrm{Fe}^{2+}\right]$ and $\left[\mathrm{HCO}_{3}^{-}\right]$, i.e. the main products of aerobic and anaerobic oxidation processes. This indicator allows determining the share of $\mathrm{Fe}^{2+}$ ions in the total products of the organic matter oxidation process, i.e. the sum of $\mathrm{Fe}^{2+}$ and $\mathrm{HCO}_{3}^{-}$ions (Fig. 8).

The Iron Index of Organic Matter Anaerobic Decay Intensity (IOMADI) has the following form:

$$
\mathrm{IOMADI}=\frac{\left[\mathrm{Fe}^{2+}\right]}{\left[\mathrm{Fe}^{2+}\right]+\left[\mathrm{HCO}_{3}^{-}\right]} \times 100,
$$

where $\left[\mathrm{Fe}^{2+}\right]$ is the molar concentration of $\mathrm{Fe}^{2+}$ ions $(\mathrm{mmol} / \mathrm{L}),\left[\mathrm{HCO}_{3}{ }^{-}\right]$is the molar concentration of bicarbonate ions $(\mathrm{mmol} / \mathrm{L})$.

The value of the IOMADI index allows to distinguish four classes of relative intensity of the anaerobic oxidation of organic matter (Fig. 8). For the discussed research area of the "Zielona" industrial waste landfill, water samples from the tested piezometers very clearly differentiate into an area where the intensity of the anaerobic oxidation process is low IOMADI index $<10 \%$ and the concentration of bicarbonate ions reach the value of $200-900 \mathrm{mg} / \mathrm{L}$. Second group of piezometers where the aforementioned process is of relatively greater importance (IOMADI index $>10 \%$ ). At the same time, significant differences between the Pz5, Pz7 and $\mathrm{P} 17$ piezometers where anaerobic oxidation is of dominant relative intensity (IOMADI index $>50 \%$ ) and samples from the Pz4, P13 and P18 boreholes where its relative intensity is relatively lower i.e. important and significant are visible. (Fig. 8).

The practical use of the IOMADI index reveals the regularity that anaerobic oxidation of organic matter occurs most

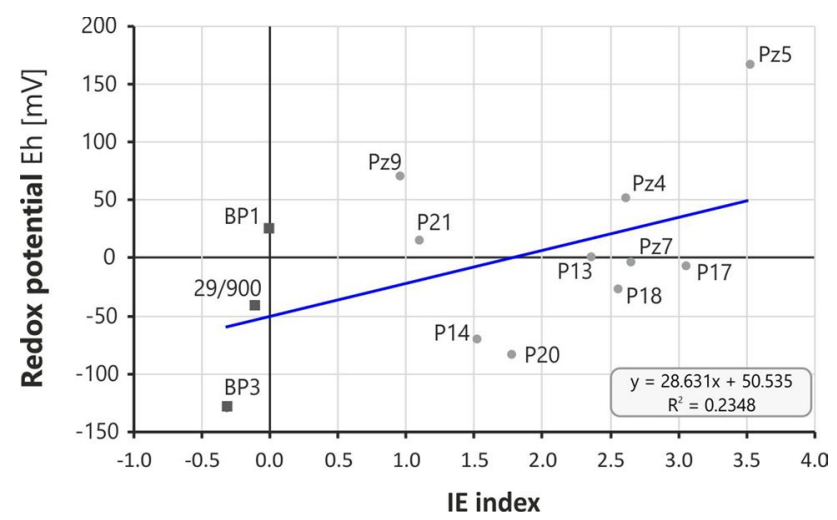

Fig. 7 Change of IE index value in examined piezometers within the Quaternary groundwater contamination plume 
intensively not in the zone where the concentration of TOC and phenol are the largest, but somewhat on the periphery of the contaminant plume where it contacts the stream of uncontaminated water. In addition, for the intensity of anaerobic oxidation of organic matter to be considered "important", i.e. reaching IOMADI index level $>10 \%$, it is necessary that the concentration of $\mathrm{Fe}^{2+}$ ions is over 100 times higher than the value for the hydrogeochemical background (i.e. IE index $>2$ ).

\section{Edge of the "redox reactor"}

Hydrogeochemical processes occurring within the contaminant plume associated with the "Zielona" industrial waste landfill run under specific hydrodynamic conditions, where the velocity of the groundwater stream moving towards the strongly draining Vistula River is within about 100 m/year. For dissolved organic contaminants due to sorption, migration retardation is observed but it is relatively small, where the limiting factor is a low content of minerals having sorption properties, as well as solid organic matter in the aquifer.

Under the conditions of contamination on the edges of the "redox reactor", there is an intermediate zone between the core of the contaminant plume and oxygenated, pure Quaternary groundwater flowing into or around the contaminant plume. Oxygen dissolved in water or incorporated in the compounds (anions) also appears in this zone. In such environmental conditions, the accompanying reaction is the oxidation of reduced forms of inorganic components, mainly $\mathrm{Mn}^{2+}$ and $\mathrm{Fe}^{2+}$, which predominate in the entire mass of contaminated water (concentration anomaly). The reaction occurs according to the general formula (Liebes 2009):

$2 \mathrm{Fe}^{2+}+\mathrm{O}_{2(\mathrm{~g})} \uparrow+4 \mathrm{H}_{2} \mathrm{O} \rightarrow 2 \mathrm{Fe}(\mathrm{OH})_{3(\mathrm{~s})} \downarrow+2 \mathrm{H}^{+}$,

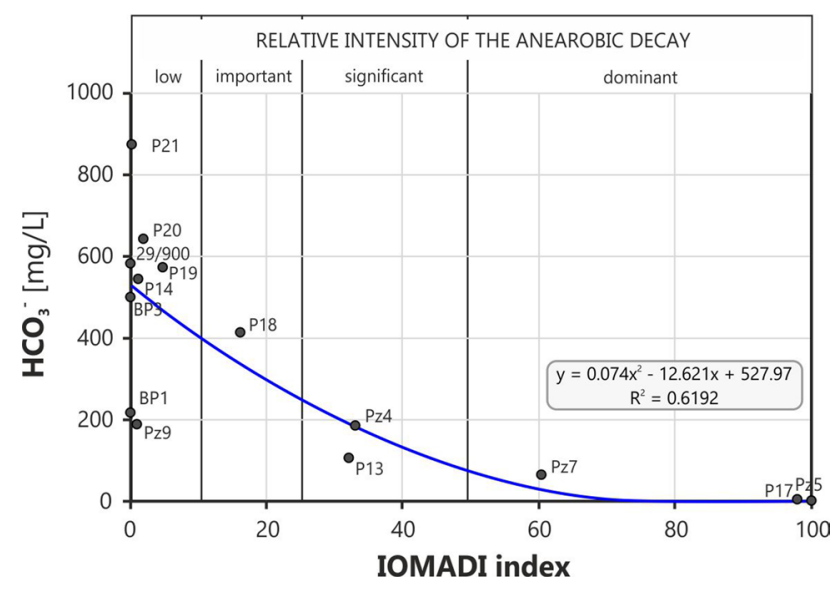

Fig. 8 Change of IOMADI index value in examined piezometers within the Quaternary groundwater contamination plume
$\mathrm{Mn}^{2+}+0.5 \mathrm{O}_{2(\mathrm{~g})} \uparrow+\mathrm{H}_{2} \mathrm{O} \rightarrow \mathrm{MnO}_{2(\mathrm{~s})} \downarrow+2 \mathrm{H}^{+}$.

Metal oxides and hydroxides precipitate from the solution and are passing into the solid phase. The precipitation of insoluble iron and manganese oxides and hydroxides is associated with very significant acidification of the environment by the resulting hydrogen ions $\left(\mathrm{H}^{+}\right)$. The mechanism presented above is responsible for lowering the $\mathrm{pH}$ to below 7 (acidic environment), which results in complete elimination of bicarbonate ion $\left(\mathrm{HCO}_{3}^{-}\right)$from the solution or reduction of its concentration. This type of situation occurs in the peripheral zones of the contaminant plume, and in particular, it has been convincingly confirmed by measurements made in piezometric holes Pz5, Pz13 and P17 (0-5.1 mg/L of $\mathrm{HCO}_{3}^{-}$).

However, due to the successive migration of groundwater and moving of the "redox reactor" in the rock mass, oxidized forms of metals under the conditions of limited oxygen availability can undergo reactions with organic matter during its anaerobic oxidation.

\section{Conclusions}

The paper presents actual results of hydrogeochemical tests for a plume of organic and inorganic contaminants occurring within an aquifer built of fine-grained Quaternary sands. The studied contaminant plume is characterised by the presence of relatively very high concentrations of organic contamination of chemical compounds. Concentrations of these substances change strongly in very different $\mathrm{pH}$-Eh conditions, practically on the entire extent of the contaminant plume, which reaches about $1.2-1.5 \mathrm{~km}$, and according to newer studies even up to $2.5-3 \mathrm{~km}$. In such conditions, with a relatively large number of piezometric holes, the focus was on assessing the processes of organic contaminants decay, which has a key role in potentially reducing environmental hazards and planning possible remediation activities.

Bearing in mind the main goal of cleaning the environment of often toxic organic compounds, it is clear that the natural processes of oxidation and degradation of contaminants have very serious limitations. Low oxygen availability is of major importance in this respect, which means that chemicals with relatively low half-life times, such as phenol, show high stability in real cases of soil and water environment pollution and may occur within it even for several dozen years.

The visible effect of redox processes under real field conditions is the occurrence of specific products in the liquid phase, i.e. within groundwater, and in the solid phase, i.e. within soils and grounds. This type of effect may be in the light of research for the contaminant plume associated with the landfill from the chemical industry, anomalies of 
concentrations of elements sensitive to changes in redox conditions, or even in a wider range of $\mathrm{pH}-\mathrm{Eh}$ changes in the environment. An anomaly can occur despite the fact that these elements are not found in large quantities in natural, unpolluted groundwater, where their level usually does not exceed several dozen-several hundred $\mu \mathrm{g} / \mathrm{L}$. The source of these elements is located within the rocks of the substrate, although often their content is very small and amounts to only a few grams per kilogram, below $10 \mathrm{~g} / \mathrm{kg}$, which is less than $1 \%$. In the case of iron and manganese, even within quartz Quaternary sands, characterised by a small amount of admixtures, there is still enough dispersed iron and manganese minerals to produce a significant anomaly of these elements in groundwater. In irrigated sandy formations, for an effective porosity coefficient $\left(n_{\mathrm{e}}\right)$ of 0.25 , groundwater has a surface contact with four times the volume and even ten times the mass of ground. As a result of water-rock interactions, it is therefore possible to start the process of transferring elements from the solid to the liquid phase, which occurs as a result of the coupling of chemical reactions including mainly redox type and bacterial activity.

The aforementioned reaction system has a limited rate of decay of organic compounds, but in the long term of several thousand years to tens of thousands of years, it has the potential for complete mineralisation of organic compounds, i.e. their transformation into inorganic components. Redox processes can occur cyclically as long as there are favourable conditions for their course, i.e. the main substrates for individual reactions will be available. In the case of contaminant plumes with organic compounds occurring in the soil and water environment, natural decomposition processes are too slow to thoroughly reduce the concentration of toxic substances in the perspective of not only years, but also decades. Nevertheless, these reactions are ongoing and not only can be identified, but one can also track their progress. It is particularly interesting that the reaction proceeds under conditions of groundwater stream displacement, which results in shifting masses of pollutants to a new location and a constant inflow of oxygenated groundwater stream. These factors cause a permanent disturbance of the system balance and stimulate the processes of aerobic and anaerobic decay of organic matter based on cyclic oxidation and reduction of elements sensitive to redox potential changes, mainly iron and manganese but also arsenic, cobalt, copper, chromium, mercury copper, selenium, antimony and uranium.

On the other hand, the occurrence of these elements in the groundwater environment, including in particular aquifers composed of Quaternary sands, where there are no minerals that are their source, is an important indicator of organic matter decay processes. Two hydrogeochemical indicators proposed in the paper allow not only to identify the zones in which the said process takes place (using the IE index), but also to quantitatively assess the intensity of anaerobic decay of organic compounds in relation to standard oxidation in reaction with oxygen from atmospheric air dissolved in water (using the IOMADI index). As part of the study, it was also established, which of course requires confirmation in other available locations, that anaerobic decay of organic matter acquires a dominant significance for systems where the concentration of iron in groundwater exceeds the average value for the hydrogeochemical background by at least 100 times (IE index $>2$ ).

Two iron indexes proposed in the paper, the IE index and the IOMADI index, cannot of course be an alternative to hydrogeochemical research, but due to the fact that they indicate the process of decay of organic compounds, they can also be helpful in the initial recognition of soil and water environment pollution with organic substances. This is important due to the fact that often, abnormally high levels of iron and manganese in shallow groundwater found in Quaternary sands and gravels are treated as having a geogenic background, where they are often associated with the decay of organic compounds supplied by sewage discharges and flowing in the stream of polluted groundwaters moving towards surface watercourses.

Iron indexes were used in a practical way for the initial interpretation of hydrogeochemical tests carried out in 2019-2020 in the zone located east of the discussed area of contaminant plumes associated with the "Zielona" landfill. It demonstrates the possibility of a much larger extent of the contaminant plume, the front of which is not in the area of an improperly made and exploited barrier intake, but even at a distance of $1-1.5 \mathrm{~km}$ to the east at a short distance from the Vistula riverbed.

The remarks and conclusions presented in this paper by no means exhaust the extensive topic, which is the study of oxidation and reduction processes in the soil and water environment. However, they are a very interesting contribution and a chance for real research on the course of these processes in field conditions, which will certainly be continued. The case of contaminant plume from the "Zielona" industrial waste site at the former "Zachem" Chemical Plant in Bydgoszcz city described in the paper is one of the most serious environmental threats in Poland, where it covers an area of about 120 ha and has an extent of up to about $2.5 \mathrm{~km}$.

Funding This work was supported by the Department of Hydrogeology and Engineering Geology AGH University of Science and Technology in Krakow (Poland).

Open Access This article is licensed under a Creative Commons Attribution 4.0 International License, which permits use, sharing, adaptation, distribution and reproduction in any medium or format, as long as you give appropriate credit to the original author(s) and the source, provide a link to the Creative Commons licence, and indicate if changes were made. The images or other third party material in this article are included in the article's Creative Commons licence, unless indicated 
otherwise in a credit line to the material. If material is not included in the article's Creative Commons licence and your intended use is not permitted by statutory regulation or exceeds the permitted use, you will need to obtain permission directly from the copyright holder. To view a copy of this licence, visit http://creativecommons.org/licenses/by/4.0/.

\section{References}

ATSDR (Agency for Toxic Substances and Disease Registry) (2011) ToxGuideTM for Phenol C6H6O. U.S. Department of Health and Human Service Public Health Service, Atlanta

Borch T, Kretzschmar R, Kappler A, Van Cappellen P, Ginder-Vogel M, Voegelin A, Campbell K (2010) Biogeochemical redox processes and their impact on contaminant dynamics. Environ Sci Technol 44:15-23. https://doi.org/10.1021/es9026248

Czop M, Pietrucin D (2017) Remediation project for the "Zielona" industrial waste site at the former "Zachem" Chemical Plant JSC in Bydgoszcz City and remediation of the soil and water environment in the area of impact of the landfill. Stage 2. Kraków (AGH-RDOŚ contract No. 1/ZP/2017) (in polish, not published)

EEA (European Environment Agency) (2014) Progress in management of contaminated sites. https://www.eea.europa.eu/dataand-maps/indicators/progress-in-management-of-contaminat ed-sites-3/assessment. Accessed 01 Apr 2020

Hammes F, Verstraete W (2002) Key roles of pH and calcium metabolism in microbial carbonate precipitation. Rev Environ Sci Biotechnol 1(1):3-7

Hendricks DW (2007) water treatment unit processes: physical and chemical. CRC Press, Boca Raton

Jankowski M (2014) The evidence of lateral podzolization in sandy soils of Northern Poland. CATENA 112:139-147. https://doi. org/10.1016/j.catena.2013.03.013

Kristensen E, Ahmed SI, Devol AH (1995) Aerobic and anaerobic decomposition of organic matter in marine sediment: which is fastest? Limnol Oceanogr 40(8):1430-1437. https://doi. org/10.4319/lo.1995.40.8.1430

Kutsuki K, Ono T, Hirose K (2007) First-principles study on electronic structure of $\mathrm{Si} / \mathrm{SiO} 2$ interface-effect of interface defects on local charge density. Sci Technol Adv Mater 8:204-207. https://doi.org/10.1016/j.stam.2007.01.008

Lerner DN, Thornton SF, Spence MJ, Banwart SA, Bottrell SH, Higgo JJ, Mallinson HEH, Pickup RW, Williams GM (2005) Ineffective natural attenuation of degradable organic compounds in a phenol-contaminated aquifer. Groundwater 38(6):922-928. https://doi.org/10.1111/j.1745-6584.2000.tb00692.x

Liebes SM (2009) Introduction to marine biogeochemistry, 2nd edn. Elsevier (Academic Press), London

Loehr RC, Matthews JE (1992) Loss of organic chemicals in soil: pure compound treatability studies. J Soil Contam 1(4):339360. https://doi.org/10.1080/15320389209383421

Narwojsz A (1989) Hydrogeological documentation of contamination migration in the area of "Organika-Zachem" Chemical Plant in Bydgoszczy City. Geological Enterprise, Warszawa (in polish, not published)

Narwojsz A (2007) Hydrogeological documentation of groundwater intake resources from Quaternary deposits in the Chemical Plant in Bydgoszczy City. Hydrogeological Enterprise. Gdańsk (in polish, not published)
Peng Z, Kenneth M, Merz KM Jr (1993) Theoretical Investigation of the $\mathrm{CO}_{2}+\mathrm{OH}^{-} \rightarrow \mathrm{HCO}_{3}^{-}$: reaction in the gas and aqueous phases. J Am Chem Soc 115:9640-9647. https://doi. org/10.1021/ja00074a032

Pierri D, Czop M, Borczak S (2017) Occurrence and migration of PAHs in Quaternary deposits in the area of the "Zielona" industrial waste dump in Bydgoszcz (northern Poland). Prz Geol 65:1144-1148 (in polish)

Pietrucin D (2013) Monitoring of the aquatic environment of an industrial area with multiple sources of pollution. Bull Geogr Phys Geogr Ser 6:43-58. https://doi.org/10.1515/ bgeo-2015-0013

Pietrucin D (2015) Migration of organic and inorganic contaminants in the aquatic environment on the example of the industrial waste site "Zielona" in "Zachem" Chemical Plant Bydgoszcz city. Doctoral dissertation at the Department of Hydrogeology and Engineering Geology, AGH University of Science and Technology in Krakow POLAND. AGH-UST Main Library (in polish)

PN-C-04566.03 (1982) Water and sewage. Research on the content of sulfur and its compounds. Determination of hydrogen sulfide and soluble sulfides by thiomercurometric method (norm, Polish version)

PN-EN 1484 (1999) Water analysis. Guidelines for the determination of total organic carbon (TOC) and dissolved organic carbon (DOC) (norm, Polish version)

PN-EN ISO 17294-1 (2007) Water quality. Application of inductively coupled plasma mass spectrometry (ICP-MS). Part 1: General guidelines (norm, Polish version).

PN-EN ISO 17294-2 (2006) Water quality. Application of inductively coupled plasma mass spectrometry (ICP-MS). Part 2: Determination of 62 elements (norm, Polish version).

PN-EN ISO 11885 (2009) Water quality-determination of selected elements by inductively coupled plasma optical emission spectrometry (ICP-OES) (norm, Polish version)

PN ISO 6439 (1994) Water quality. Determination of phenol index4-aminoantipyrine spectrometric methods after distillation (norm, Polish version)

Rashkeev SN, Fleetwood DM, Schrimpf RD, Pantelides ST (2001) Defect generation by hydrogen at the $\mathrm{Si}-\mathrm{SiO} 2$ interface. Phys Rev Lett 87(16):165506-1-165506-4

Rashkeev SN, Fleetwood DM, Schrimpf RD, Pantelides ST (2002) Dual behavior of $\mathrm{H}^{+}$at $\mathrm{Si}-\mathrm{SiO}_{2}$ interfaces: Mobility versus trapping. Phys Rev Lett 81(10):1839-1841. https://doi. org/10.1063/1.1504879

Sah CT (1996) Fundamentals of solid-state electronics: solution manual. Uto-Print, Singapore

Schout G, Hartog N, Hassanizadeh SM, Griffioen J (2017) Impact of an historic underground gas well blowout on the current methane chemistry in a shallow groundwater system. Proc Natl Acad Sci USA. https://doi.org/10.1073/pnas.1711472115

Sinsabaugh RL (2010) Phenol oxidase, peroxidase and organic matter dynamics of soil. Soil Biol Biochem 42(3):391-404. https://doi. org/10.1016/j.soilbio.2009.10.014

Smarzyński A, Sadowski O (2005) Barrier intake as part of contaminated groundwater capture system from the landfill area at Zielona Street in Bydgoszcz City. Hydrogeology of Kujawy region and Lower Powiśle. Field Session Guide, Toruń (in polish)

Vaishnav DD, Babeu L (1987) Comparison of occurrence and rates of chemical biodegradation in natural waters. Bull Environ Contam Toxicol 39(2):237-244

van Schie PM, Young LY (2007) Biodegradation of phenol: mechanisms and applications. Bioremediat J. https://doi. org/10.1080/10588330008951128 (published online: 1-18) 
Weckwerth P, Chabowski M (2013) Heavy minerals as a tool to reconstruct river activity during the Weichselian glaciation (Torun Basin, Poland). Geologos 19(1-2):25-46. https://doi.org/10.2478/ logos-2013-0003

Weiner ER (2008) Applications of environmental aquatic chemistry: a practical guide, 2nd edn. CRC Press, Boca Raton
Publisher's Note Springer Nature remains neutral with regard to jurisdictional claims in published maps and institutional affiliations. 